\title{
Political risk in the age of multinational corporations
}

\author{
POLITICAL RISK: HOW BUSINESSES AND ORGANIZATIONS CAN \\ ANTICIPATE GLOBAL INSECURITY \\ Condoleeza Rice and Amy B. Zegart \\ 2018. New York: Twelve (Hachette Book Group). 307 pages
}

Political risk should be an increasingly important component of any multinational enterprise's (MNE) global strategy, as the post-cold war era has created a political and social environment that is less predictable for executives to manage-and plan-their corporations' futures. The authors, Condoleeza Rice, former U.S. Secretary of State under President George W. Bush, and the Denning Professor in Global Business and the Economy, Stanford Graduate School of Business, and her coauthor, Amy B. Zegart, the Davies Senior Fellow at the Hoover Institute, and former management consultant at McKinsey \& Company, come to this project with impressive credentials. In the book, an outgrowth of an M.B.A. class they co-teach at Stanford, the authors argue that governments are no longer "the only important arbiters of business" (p. 4); today, there are multitudes of important stakeholders who are capable of creating political risk for MNEs.

In chapter one, Rice and Zegart define 21st century political risk as "the probability that a political action could affect a company in significant ways (p. 5)." Presumably, the perpetration of this "political action" can be by the firm or by one of its many stakeholders. Here, the authors unveil their basic political risk framework and present their guiding questions for effective risk management. This chapter also lays out the topics they will cover in the remainder of the book, including understanding and prioritizing political risk, taking advantage of global opportunities and efficiencies without unduly increasing vulnerability, and creating a continuous learning cycle to anticipate, handle, and recover from political risk crises, to name a few.

Chapter two illustrates that political risk, which in the 20th century was primarily driven by government actions, is now a crowded landscape of different actors (in addition to governmentally generated political risks). These actors now employ the latest information and media technologies to virtually organize collectively and have their political message "go viral." The authors identify five intersecting levels of action generating political risk: individuals, local organizations, national governmental actors and their institutions, transnational groups, and supranational and international institutions. Moreover, Rice and Zegart have conveniently cataloged their political risks under ten topics: geopolitics, internal (country) conflict, public policy change (including laws and regulations), government breaches of contract, public corruption, national extra-territorial reach, natural resource manipulation, social activism, terrorism, and cyber threats.
In chapter three, Rice and Zegart explain the megatrends in business, technology, and politics since the end of the Cold War. While MNEs now have greater business opportunities, they also face greater variation in political risk. For example, globalization has allowed MNEs to create longer, leaner global supply chains to take advantage of lower wages and shipping costs, coupled with improved inventory management to customize products for different market segments. The downside of this increasing efficiency, product differentiation, and profitability, however, has been MNE supply chains operating in higher risk locations, thus exposing firms to cumulative risk vulnerabilities often difficult to recognize. In addition, social activism, practiced by individuals and through collective action, has been facilitated by low-cost, connective technologies that both governments and businesses must deal with as events "go viral" without warning. Furthermore, Rice and Zegart identify "four shocks" affecting the political and business worlds. First, the attacks of September 11, 2001, showed that nonstate actors were capable of great harm. Second, the 2008 financial crisis resulted in increased government intervention and the rise of political populism. Third, the Arab Spring's political unrest placed further stress on Middle Eastern and North African governments. Fourth, China's rise and the re-emergence of Russia in international affairs have challenged the international order when America is turning inward.

Chapter four explores why good political risk management is so difficult to undertake. The authors conclude that, while studies consistently find that company executives know that they are not good at political risk management, many companies still do not integrate political risk analysis into their overall risk management. Rice and Zegart explain why this scenario so often exists with their "Five Hards": Political risk is hard to reward (especially for fixing problems that never happened), hard to understand, hard to measure, hard to update, and hard to communicate. There are underlying reasons that contribute to these "Five Hards", including that political risk usually involves difficult to measure qualitative factors, such as the national mood or policy stability, while cognitive biases are capable of distorting human probability calculations. Also noteworthy is that once an MNE investment decision is made, many companies simply do not update their political risk assessment on it.

In chapter five, Rice and Zegart discuss their political risk framework. While acknowledging that political risks are context specific, they argue that core competencies for management to get right include: understanding risk, analyzing risks, mitigating the residual risks that cannot be eliminated, and then establishing a response capability that enables effective crisis management and continuous learning. 
Using their political risk framework, the authors convincingly illustrate how Royal Caribbean International successfully managed a political crisis involving their cruise line and the 2010 Haiti earthquake. Rice and Zegart skillfully apply the framework to the context of the specific situation, and further compare each competency utilized by Royal Caribbean's executive management to an earlier case involving SeaWorld and their management's unsuccessful handling of an employee's death by a killer whale.

Chapter six provides many examples on how to improve a company's understanding of its political risk appetite, foster a shared understanding across the company, and reduce potential blind spots. The authors bring attention to the fact that the tolerance for political risk may vary by industry and company. Subsequently, they recommend assessing the key components of a company's value chain and having executives, or other experts, list potential risks that could have an adverse impact. Using several examples, such as the Lego Group's use of a two-by-two matrix that identifies the probability of a risk occurring and its likely financial impact, Rice and Zegart highlight the fact that improving the understanding of a company's political risk may even allow it to be more aggressive. Techniques for sharing the understanding of the desired level of risk across the company can range from frequent discussions at meetings, holding risk assessment tournaments, and infusing it into strategic planning. Using the example of Kirk and Spock from Star Trek, the authors also promote having diverse backgrounds and opinions, imagination and logic, to enhance the company's ability to identify emerging challenges, reducing blind spots, before it misses the boat.

In chapter seven, Rice and Zegart suggest that the best political risk analysis follows a scientific approach that is both rigorous and allows for thinking outside the box, much like a great physicist might be both systematic and logical while still imaginative. When gathering data, analysts should take care to ask the right questions and be comprehensive in scope to avoid arriving at the wrong conclusions based on a biased search. Furthermore, it is important to not only identify pertinent facts and be rigorous, but also include perception and emotion in the approach to avoid being trapped into specific mindsets and paradigms that are too narrow. The authors suggest engaging in scenario planning and reperceiving drivers and possibilities as some of the many tools that can be adopted. Furthermore, integration of political risk may require a commitment from top-level executives to forward-deploying risk officers and joint problem solving.

Chapter eight begins with the realization that even though companies that understand political risk can engage in rigorous and comprehensive approaches toward identification and analysis, not all risk can be avoided. Thus, the authors shift the focus away from lowering and avoiding risk, to lessening, or mitigating, its impact on the organization. Using the example of the Global Operation Control Center of FedEx, Rice and Zegart promote having action teams that can manage the residual crises, which will inevitably arise, from beginning to end. Such teams and risk management systems should include early warning indicators, fast action responses, preplanned mitigation strategies, and postcrisis debriefing session to share lessons learned. Effective identification systems allow for a categorical prioritization, lowmedium-high, based on value and vulnerability. Using the U.S. Nuclear Triad (i.e., multiple formats to deploy nuclear payloads), the authors emphasize that having multiple approaches, or a repertoire of strategies, toward crisis mitigation is imperative in the event one approach cannot be used or is ineffective. Contingency plans should clearly identify roles for teams' members and include routines for coordination of strategic plans and actors.

The authors use examples and anecdotes in chapter nine that show how to respond to crises and in some cases how not to. Rice and Zegart reemphasize that it is better to avoid having a crisis altogether, and never needing to respond, but they do provide more key lessons should the need arise. Quickly-yet thoroughly-assessing a crisis, but in some cases learning from near misses, is the first step toward an effective response. Establishing an appropriate crisis management team, where each person knows his or her role and can emphasize the values of the company, rather than attributing blame, is the next stage. The authors emphasize that great care must be shown when companies decide to respond to challenges, or tell their story, so that fires are extinguished quickly rather than intensified. Rice and Zegart use the Johnson and Johnson case, where a perpetrator replaced Tylenol with poison-laced pills in the early 1980s, as an example of taking responsibility and quick action to save a brand. They alternatively use the examples of the British Petroleum oil platform explosion in the Gulf of Mexico and United Airlines, where a passenger was violently dragged off an overbooked flight, of what not to do. In these cases, the respective company chief executive officers did not take responsibility, or show contrition, and instead made callous public statements that only drew more attention to the situation, making it worse. The authors present such good and bad examples of crisis response as opportunities for continuous learning, both for the companies involved and others that may face similar challenges in the future.

In chapter ten, the authors provide a summary and table of the framework they developed and use in their political risk course that highlights key elements they have covered in the previous four chapters. This includes the creation of abilities to understand, analyze, mitigate, and respond to political risk. Rice and Zegart go on to suggest that, like the muscles of an athlete, aspects of the political risk management systems and processes must be exercised to be strengthened and abilities enhanced. In some industries, this is more crucial than in others.

Both Rice and Zegart bring a wealth of knowledge from their extensive academic and employment experience to the issue of political risk analysis. They offer a fresh perspective to the area of business political risk analysis, where most business scholars approach this subject from the "inside" (the firm) "out" (the external environment), rather than an "outside-in" approach from the international relations/political science perspective. What Rice and Zegart have done in their book is to broadly translate what other authors have done in the realm of business political risk analysis (often performed by staff analysts or consultants) and moved this increasingly important strategic responsibility into the bailiwick of the organization's strategists (executive management and boards of directors). Thus, the authors' business political risk framework allows this important component to be actively considered by the key company decision-makers responsible for the organization's strategic planning.

Yet, the book's shortcomings (parlayed in a constructive way to enhance political risk management effectiveness) should not be 
ignored. For example, in Chapter 7, there was no mention of "tricky situations," such as regulatory expropriation nor handling country World Trade Organization exceptions regarding public health and safety (e.g., keeping products out of a domestic market) or "national security" concerns (e.g., keeping competitors out, and exploiting the "infant industry" defense). In addition, in Chapter 8, the authors' commentary on industry self-regulation, that is, industry self-regulation is useful to avoid further government regulation, ignores the use of industry self-regulation as a positive private ordering mechanism for a more flexible, adaptable industry response to changes in the technological and competitive environment (vis-à-vis other industries and nations).

Overall, the authors have attempted to convert their class on Managing Global Political Risk into a book format that perhaps resembles the pedagogy and lesson progression a student might encounter during the semester at Stanford. However, while the authors deftly employ a foundation of the subject, a framework for organization, and scatter many real-world examples into the text like we might expect to find in a comprehensive business course, the fine-grained details on managerial implementation that are likely to emerge during say, a classroom discussion or exercise, are sadly lost in translation.

In Chapter 6, for instance, the authors highlight the importance of fostering a shared understanding of risk appetite across the company and use examples of efforts at Lego, Disney, and Cemex. However, most examples occupy only a few paragraphs and there is not extensive detail on the implementation of knowledge transfer process that occurs between the executives and lower-level employees. Cemex, for instance, often uses middle managers to bridge the knowledge transfer gap between executives and lower-level employees, as they can relate to both levels, and rotates them to different locations around the world to foster an understanding of best practices. Using an example in the classroom, like the chief risk officer at Cemex, Enri- que Alanis, "evangelizing about risks (p. 141)," is likely to produce further discussion, where more details about that evangelizing, or the knowledge transfer process mentioned here, may emerge. The authors, it seems, have either failed to recognize that this approach taken in class will not translate in the text, or perhaps have elected to keep the lessons general in nature so that the book is more palatable for their target audience.

\section{ORCID}

Thomas A. Hemphill (D) https://orcid.org/0000-0001-8325-5479

Thomas A. Hemphill (D) Keith J. Kelley

School of Management, University of Michigan-Flint, Flint, Michigan

\section{AUTHOR BIOGRAPHIES}

Thomas A. Hemphill (thomashe@umflint.edu) is the David M. French Distinguished Professor of Strategy, Innovation, and Public Policy in the School of Management, the University of Michigan-Flint. His research in global business and international political economy has been published in the Journal of Global Responsibility, International Business Review, Management International Review, Multinational Business Review, and Thunderbird International Business Review.

Keith J. Kelley (keithkel@umflint.edu) is an Assistant Professor of International Business in the School of Management, the University of Michigan-Flint. His research in global business and strategy has been published in the Journal of Global Responsibility, Journal of Business Research, Multinational Business Review, and the International Journal of Emerging Markets. 